\title{
The Advantage and Development Strategy of China's Higher Education Overseas Consumption Service Trade
}

\author{
GuohuaZhou \\ The Party Committee Organization Department, Jiangsu University, Zhenjiang, Jiangsu, P. R. China
}

Email address:

ghzhou@mail.ujs.edu.cn

To cite this article:

Guohua Zhou. The Advantage and Development Strategy of China's Higher Education Overseas Consumption Service Trade. Science Journal of Education. Vol. 3, No. 5, 2015, pp. 114-118. doi: 10.11648/j.sjedu.20150305.13

\begin{abstract}
Overseas consumption has become the most important way of international service trade in higher education. From the global perspective, there exists serious imbalance in the overseas consumption for higher education service trade. However, in the context of the growing popularity of global Chinese, the service our higher education provides for overseas students remain obvious prominent advantage in the term of traditional disciplines and service prices. Analysis of the advantages of the current higher education consumption in overseas service trade to develop and implement appropriate strategies is a very important and urgent practical issue for the promoting China's international trade in higher education services in the near future. The government must provide huge support for foreign students education system; colleges and universities must add international education, strengthen the teaching of Chinese as a foreign language, meet the students needs of local Chinese curriculum and discipline, so that a suitable learning and living environment for overseas studented can be created.
\end{abstract}

Keywords: Overseas Consumption, Service Trade, Higher Education

\section{Introduction}

Foreign consumption services trade in higher education is often referred to as a service trade for overseas students, a economic acitivity of studying, being serviced at abroad and bringing economic beneifts to recepient country. China's overseas consumption service is education service for the people of various countries. With the high speed of globalization and deep communicating of cultures of different countries, the overseas consumption service has been brought into our attention in that it brings huge economic benefits to the country, which is closely related to huge foreign exchange flow. This service trade has become an important constitute of international trade, an important channel of exporting goods to earn foreign currency for oveseas students' recepient country, becoming an important driving force in economic growth for students receiving country. However, there exist various problems in these service trade, such as weak foundation and international competitiveness, lack of management experience, and imperfect legal system. However, facing unprecedented international education and trade opportunities, China's higher education must face challenges. Through effective policy guidance, advantage analysis, risk aversion, China's higher education overseas consumption services trade can still play its great potential of developing and bright prospect in the future.

\section{The Connotation and Value of Foreign Consumption Service Trade in Higher Education}

Consumption abroad plays an important role in the international education service trade, a main form of international trade in education services, and a form of education industrialization and the highest degree of opening-up. From a global perspective, the majority of WTO member states have a cautious attitude towards the opening-up market of the education. But higher education overseas consumption services trade is different for the following aspect. On one hand, higher education is more open and the internationalization development trend is more obvious, compared to the obligational education; on the other hand, compared with other trade in educational service, consumption abroad have fewer restrictions. Therefore, in order to pursue the maximum benefit and expand their international influence, gain greater profits from overseas consumption service trade, more and more countries take the foreign consumer education service trade as an important way to earn foreign exchange, to stimulate 
domestic economic growth and make up for the shortage of higher education funds.

International consumption service trade in higher education has made considerable progress in recent years, and the trade volume has been increasing, occupying the absolute proportion of the entire education service trade. On one hand, this education service trade can create a direct economic benefit for countries of absorbing overseas students by charging overseas students tuition and fees and school during the studying, such as accommodation, catering, shopping, tourism, entertainment, transportation and other costs can obtain huge economic benefits. On the other hand, quite a few students studying in developed countries will not return to their home country after their study, but stay in the recipient country to create economic value, and these countries benefits more from it. Data indicate that the United States University has become the fifth major industries following the arms, electronics and other industries. [1] Foreign consumer education services trade has also become an important source of foreign exchange in New Zealand, France, Canada and other countries; they have to take preferential policies to attract foreign students to get profit. Thus, the trade volume of foreign consumption is much higher than other methods of foreign exchange earnings, and has become the most important choice of educational service trade.

The most striking feature of the international consumption education services is the rapid expansion of foreign students, and the sharp rise in the trade volume of these education services. This is because the overseas consumption and education service trade not only has obvious value, but also the potential added value. Although the added value of consumption education service trade abroad is difficult to quantify, but it has more value than economic value, which affects a country's competitiveness and influence in the international community in the future. The huge added value of foreign consumption education service trade has been recognized by many countries. In many countries, it is an important way to expand their international influence. [2] Thus, to develop vigorously the overseas consumption education service trade can not only get the direct economic benefits by overseas students tuition fees and living expenses, also get more added value and potential by receiving students, and finally get the political and economic double income.

\section{The Status of International Higher Education Consumption Abroad}

Looking from the actual development of foreign consumption education service trade in various countries, the international consumption services trade in higher education shows clearly the following characteristics.

\subsection{The Unbalance}

Due to the differences in economic, social and cultural development, global consumption education service trade abroad also inevitably formed a non-balanced state, which exists between the developed and developing countries extremely. Compared with the developing countries, developed countries own the overwhelming dominance, which is obviously reflected in the fact that students and education expenses are, for the most part, flowing from developing countries to developed countries. Meanwhile, the national consumption education service trade in the developed countries is also not balanced. This imbalance is also reflected in the flow of foreign consumer education services trade. A large number of foreign students in the developed countries have brought a lot of foreign exchange income and other intangible benefits, while developing countries have lost a lot of foreign exchange. International students always flow from economic underdeveloped countries to developed countries, forming a one-sided situation; this is the most prominent feature of international consumption of education service trade.

\subsection{The Obvious Influence of the Political Economy}

The market of international students has a hidden sphere of influence, and has a strong geopolitical color. As the dominant role of America in the overseas conumption education service, the United States attracts students from all over the world by its strong economic strength and international influence, but the United States consumption service trade also has the geopolitical character, its main export market in education is Asia, namely Japan, China, South Korea, China Taiwan, India, Malaysia and Indonesia, accounting for 58\% of American exports of education services, followed by the export market is Europe and Latin America. [3] After the 1980s, economic factors or economic interests become the main factors of the foreign consumption education service trade in most countries and regions. At present, many countries and regions open the source of wealth and increase revenue for colleges by recruiting a large number of full fee paying students for the country. It has become the key factor to promote the international consumption of education service trade development.

\subsection{The Relatively Higher Fee}

International students are seen as an important source of revenue by host countries, and worldwide higher education expenditure cuts and deepening of University marketization make the income becomes a more important goal, by charging higher fees to achieve educational exchange.

\subsection{The Promotion of Economic and Trade Globalization}

The globalization process provides the impetus for the development of foreign consumption education service trade. Under the background of economic globalization, a country's education must integrate into the world economic and social development, which requires that the education should foster open type talents with international vision and international competition ability, which prompted the talent flow among all 
the countries in the world, leading to the boom of studying abroad. [4]

\section{The Advantages of Higher Education Consumption in China}

\subsection{The Advantages of the Chinese Language Service}

Language is an important tool for human beings to transmit information, to exchange culture and to learn science and technology. From the 21 st Century, with the rapid development of China's economy and the increasing international status, the international trend of Chinese language is increasing. According to the statistics, at present more than 2100 Universities in 85 countries around the world are teaching Chinese, otherwise, tens of thousands of primary and secondary schools, social institutions are also teaching Chinese language and the number of people learning Chinese already amounted to 30 million, the national distribution of the Chinese learning but also a very wide range. China's increasingly powerful and unique charm of Chinese culture make the international market for Chinese language has a huge demand. The mainland China is an important base of Chinese language education. At present, more and more people choose to learn Chinese and the demand of learning Chinese is increasing, we should make full use of this kind of demand, accepting foreign students with large-scale, providing Chinese education service directly by the way of transnational education, this is our advantage. At present, the Chinese Proficiency Test (HSK) has been extended to the 26 countries of the world, and there is still more than 20 cities are applying for a new examination site. In recent years, the number of foreign and domestic participants in the Chinese Proficiency Test has been largely increasing each year. [5] Therefore, we should promote a large number of foreign students to come to our country to study the professional course at the time of taking the advantage of Chinese output.

\subsection{The Awareness of International Education in China's Universities}

Since Since the reform and opening up, the competitiveness of International Education in universities is becoming more and more clear, and is being actively exploring new areas of the market in China. The level of international education is improving, the category is increasing. The University's initiative competition idea is being implemented to the university to the efficiency and benefit of study abroad. [6]In addition, administrative departments of education idea of international students has also transformed quickly from a single foreign cultural and political thought category to the economic category, by the change of the market value of exchange idea of "support and giving thought" to" provide and compensation ". Finally shift the true right of international education to the university gradually.

\subsection{Unique Advantage of the Traditional Discipline in Chinese University}

In the current international education market, attracting international students mainly rely on the university discipline advantage. The history of higher education in China is long, some disciplines with Chinese characteristics such as Chinese, history, philosophy, architecture, medicine, etc. are so strong that have certain strength in international education market. As China is a country with a rapid economic growth and great potential for development, foreign students' need of knowing the Chinese culture, economy and society increase day by day. Therefore, the traditional disciplines still have a large number of demands in the international market. China's higher education should continue to strengthen the development of traditional disciplines, improving the quality of education by the curriculum reform.

\subsection{Relative Advantage in the Price of Accepting Foreign Students in China}

Compared to high cost of studying in the west countries, China's cost includes tuition fee and living expense, which is cheaper than western countries, whose ratio is about 1:7. In engineering, for example, for the students from countries with backward economy, learning in China is not only practical but also cheap. Even under the charges full cost, due to the lower overall level of consumption, cheaper teacher labor price, the tuition for engineering disciplines student is also much lower than developed countries, so the overall cost of studying in China is much cheaper than in developed countries, higher education in our country has obvious advantages of price competition. [7]

\subsection{Obvious Advantage of the Emerging Disciplinein Higher Education Market}

The development of science and technology promote the emergence of a large number of emerging disciplines, investment in emerging disciplines is the development trend of world education. Current university inter-discipline has far exceeded the traditional interdisciplinary areas, such as film combined with network technology in digital arts; social network and learning is a combination of social media subject; the combination of movies and computer development of the interactive movie subjects. Compared with the traditional disciplines, these new disciplines or emerging professional are more attractive to international students, and the development of the cost of these emerging disciplines is relatively not high. [8] In recent years, our country's universities develop closely with the development of science and technology synchronization, continuing to choose according to the change of international market demand. Emphasizing on the investment of some new disciplines and marginal disciplines, forming a number of competitive and characteristic new disciplines, which is one of the advantages of attracting foreign students. [9] 


\section{Countermeasures and Suggestions on the Development of China's Higher Education Consumption Abroad}

The international competition of the service trade in higher education will be more intense in the future. At present, international consumption of education service trade has presented extreme imbalance, which is determined by a country's economic and cultural development level. In order to attract more foreign students study in China, China also needs to take more and more appropriate strategies to be more attractive. Overseas consumption education service trade is a tricky work, which needs the support of the government's macroeconomic and microeconomic policies. Therefore, only to be in accordance with WTO conventions and learn from foreign advanced experience, taking various measures to attract students studying in China to broaden the channels, can promote the rapid development of China's consumption of higher education service trade. [10]

\subsection{Changing Government Functions to Overcome Institutional Barriers}

Foreign countries regard international education service as a trade, an important part of economic development. With the guidance of the concept of using means of the operation of the market, government in every country can give positive support in policy, making education service trade international. The educational system of our country is formed under the long-term planned economy system, education lies in the monopoly system for a long time, and its competition consciousness is poor, efficiency low , university lacking of educational autonomy. In recent years, although our country has achieved a breakthrough in educational system, but education idea, operation system, the management mechanism, teaching content and teaching methods are still relatively old, and some institutional obstacles become the fetters restricting the development of education. Therefore, we want to introduce a new competition mechanism in the field of education, promoting a number of schools to improve quality and efficiency, becoming the pioneer attracting foreign students to study in China. [11]At the same time, we need to rationalize the relationship between the government and school realize the transformation of government functions, establish and improve the new management mechanism, strengthen the service consciousness of the government; give full play to the market regulatory role, and strive to build a good school, social environment and order, protect and promote fair competition.

\subsection{Creating an Inclusive Learning Environment for International Students}

Receiving a large number of foreign students is social system engineering to create a suitable environment for foreign students to live and study, and eliminate the doubts of foreign students. Expanding foreign students education scale, not only means the expansion of the scale of colleges and universities which has received foreign students, but also means there is a need for more colleges and universities to participate in receiving foreign students, and it's a new problem and challenge for the colleges and universities and their communities. [12]The government should introduce effective measures as soon as possible to solve the students' worries, so that they can live and learn happily.

\subsection{Adding the International Education and Teaching Content}

One is to expand humanities and social science curricula, such as establishing international trade, international finance, international relations, regional culture, history and other international education program, to make the students accept correct reflection of the international social, political, cultural, economic, historical and other "full bit International Education". Second, foreign language education should be strengthened in order to grasp the tools of international exchange, international dialogue, international negotiations, and international research to develop international students' international vision. Third, foreign practical professional, training more talents engaged in international affairs should be added to adapt to the increasingly frequent international trade and diplomatic activities.

\subsection{Reaching a Mutual Recognition of Qualifications with Various Countries in the World}

Mutual recognition of academic qualifications is also known as the credit swap and degree equivalent. With the internationalization of higher education, credit system, degree system, and academic title system gradually tend to be uniform among countries. That is, the national institutions can be mutual recognition of credit courses, and each school degree certificate can be obtained. [13] During the development of the service trade of consumption education for the foreign countries, it is very important to have a certain quality standard. At present, higher education doesn't have a unified international quality assurance framework, foreign students aren't sure if they accept the qualified higher education, and if the certificate can be recognized in the foreign labor market. Speeding up the introduction of the mutual recognition of international common vocational qualification among the member countries of WTO, it is the prerequisite for the implementation of foreign consumer education service trade.

\subsection{Strengthening the Teaching of Chinese as a Foreign Language}

Our country uses the form of HSK (Chinese Proficiency Test) to assess international students' level of Chinese. In countries where the overseas Chinese are concentrated, overseas Chinese and their children are often plagued by the education of Chinese and the education of the state of the country. In view of this situation, we can make full use of the 
advantage that universities has been engaged in teaching Chinese as a foreign language, strengthening the Chinese education home and abroad, especially in foreign country, expanding the HSK test centers to meet the need of foreign students who want to attend Chinese university and enhance the international reputation of China's colleges and universities. At present, many countries in the world strengthen teaching of the dialects one after another in order to eliminate the student language barriers and attract more foreign students. [14]

\subsection{Strengthening the Curriculum Reform in the International Perspective}

At present, there is a big difference in the setting of the foreign education curricula between foreign countries and ours. Although there are more international education curricula, students lack the enough time to autonomous learning and many foreign students have difficulties adapting to this. University must strengthen the course reform to cultivate high quality students with wide profession. Firstly, studying education curriculum abroad pay attention to the cultivation of the unity of planning and learning objectives, closely linked to study the actual situation, reduce some of the lack of practical courses, in particular, to reduce non professional courses of students at their own expense, not practical. Second, the university should take the initiative to adapt to the permeation of liberal arts and science, interdisciplinary and comprehensive development trend, some of the emerging discipline, interdisciplinary and cross disciplinary courses, in order to conform with international university credit system, to ensure that students with fully independent choice of the opportunity. [15] Thirdly, colleges and universities should take the initiative to understand the demand of the international talent market and the latest development of international university curricula. A successful experience of the curricula's reform should be absorbed and learned. The developing trend of international education reform should be followed closely. [16] New and advanced courses should be introduced and set up. On the basis of improved structure of college curricula, they should be adjusted flexibly in terms of the market need.

\section{References}

[1] Jin Xibin. Research on International Education Service Trade [M]. Fujian Education Press. 2012:124.

[2] Cheng Jinkuan. A Comparative Study of Soreign Consumption Policy of Higher Eeducation in the eEducation Service Trade [J]. Education and Modernization, 2008, (1):3-10.

[3] Jin Xibin. Research on International Education Service Trade [M]. Fujian Education Press. 2012: 138.

[4] Jin Xibin. Research on International Education Service Trade [M]. Fujian Education Press. 2012: 142.

[5] Jin Xibin. Research on International Education Service Trade [M]. Fujian Education Press. 2012: 221.

[6] Wang Peigen. Economics of High Education [M]. Economic Management Press, 2014: 406

[7] Wang Peigen. Economics of High Education [M]. Economic Management Press, 2014: 408.

[8] Jin Xibin. Research on International Education Service Trade [M]. Fujian Education Press. 2012: 160.

[9] Jin Xibin. Research on International Education Service Trade [M]. Fujian Education Press. 2012: 166.

[10] Wang Peigen. Economics of High Education [M]. Economic Management Press, 2014: 409.

[11] Chen Xuefei. The Cost and Benefit of International Education: Study on the Benefit of the Public Benefit in China since the rReform and Opening up [M]. Beijing, Educational Scientific Press, 2013:75

[12] Sun Xiaobin: The Justice and Benefit of Education: A Study on the Policies of the Chinese and Foreign Educational Economy [M]. Shanghai, Huadong Normal University Press. 2015:182.

[13] Jin Xibin: Theory, Policy and Measures-International Education Service Trade [M]. Fujian Education Press, 2005:91.

[14] Jin Xibin. Education Capital - Specification and Operation [M]. Sichuan Education Press, 2008:235.

[15] Du Yuhong. Imbalance in Educaiton [M]. Beijing: Beijing Normal University Press, 2007:162.

[16] Lou Chengwu. Educational Economy and Management [M]. Renmin University of China Press, 2011:117. 